\title{
Timeliness of epidemiological outbreak investigations in peer-reviewed European publications, January 2003 to August 2013
}

E C van de Venter (emily.vandeventer@nhs.net) ${ }^{1,2}$, I Oliver $^{3,4}$, J M Stuart ${ }^{4}$

1. Public Health England, Bristol, United Kingdom

2. South West Public Health Training Programme, Health Education South West, Bristol, United Kingdom

3. Field Epidemiology Service, Public Health England, Bristol, United Kingdom

4. School of Social and Community Medicine, University of Bristol, Bristol, United Kingdom

Citation style for this article:

van de Venter EC, Oliver I, Stuart JM. Timeliness of epidemiological outbreak investigations in peer-reviewed European publications, January 2003 to August 2013. Euro Surveill. 2015;20(6):pii=21035. Available online: http://www.eurosurveillance.org/ViewArticle.aspx?Articleld=21035

Article submitted on 16 February 2014 / published on 12 February 2015

Timely outbreak investigations are central in containing communicable disease outbreaks; despite this, no guidance currently exists on expectations of timeliness for investigations. A literature review was conducted to assess the length of epidemiological outbreak investigations in Europe in peer-reviewed publications. We determined time intervals between outbreak declaration to hypothesis generation, and hypothesis generation to availability of results from an analytical study. Outbreaks were classified into two groups: those with a public health impact across regions within a country and requiring national coordination (level 3) and those with a severe or catastrophic impact requiring direction at national level (levels 4 and 5). Investigations in Europe published between 2003 and 2013 were reviewed. We identified 86 papers for review: 63 level 3 and 23 level 4 and 5 investigations. Time intervals were ascertained from 55 papers. The median period for completion of an analytical study was 15 days (range: 4-32) for levels 4 and 5 and 31 days (range: 9-213) for level 3 investigations. Key factors influencing the speed of completing analytical studies were outbreak level, severity of infection and study design. Our findings suggest that guidance for completing analytical studies could usefully be provided, with different time intervals according to outbreak severity.

\section{Introduction}

The International Health Regulations (2005) stipulate that each State Party is required to ensure they have the capacity to respond 'promptly and effectively to public health risks', such as outbreaks of communicable diseases [1]. The timeliness of outbreak investigations is vital for containing outbreaks and preventing further cases, minimising the impact of an outbreak on both patients and health services, yet despite this, no guidance or standards currently exist regarding what might be considered a timely investigation.
A national Field Epidemiology Service (FES) was formed within Public Health England (PHE) in April 2013, following reforms to the health system in England under the Health and Social Care Act 2012 [2]. The FES aims to improve the consistency of high-quality epidemiological investigations. Hence its formation prompted the consideration of whether specific guidance on the timeliness of outbreak investigations was feasible and, if so, what should be recommended.

Current guidance from PHE [3] states that outbreak reports should be completed within 12 weeks of the formal closure of an outbreak, a common standard for outbreaks within England classified as level 2 or above (Table 1). Such outbreak reports are compiled for internal purposes, to detail the steps within and results of an outbreak investigation, they may or may not include an analytical study (case-control or cohort, for example) and will not necessarily lead to publication in a peer-reviewed journal. No further guidance or standards currently exist to inform what might be considered high quality in terms of timeliness.

We sought to review specific time intervals within epidemiological investigations, those from declaration of an outbreak to hypothesis generation and hypothesis generation to the availability of analytical results to inform the actions of relevant authorities. This review aims to summarise these time intervals in published outbreak investigations with cross-regional, national or international implications (using PHE definitions for level 3, 4 and 5 outbreaks, as in Table 1) to assess the feasibility of developing PHE guidance for the timeliness of analytical studies in outbreak investigations and whether separate standards for different outbreak levels would be appropriate. Such guidance or standards could be used to inform service improvement and/ or monitor performance in England and could be similarly developed in other countries. 


\section{Methods}

MEDLINE, Embase and Eurosurveillance were searched using the search terms 'outbreak', 'case-control' and 'cohort' to identify outbreak investigations in Europe published between 2003 and August 2013 and which included an analytical epidemiological study. Papers were included if they met the following criteria: they reported on an outbreak occurring within Europe; were published since 2003 and the outbreak occurred in 2000 or later; were deemed to be level 3 or above (Table 1); were available in English, French, Spanish, German, Greek or Italian; and an analytical study was carried out (e.g. a case-control or cohort study) (Box).

Time intervals from outbreak declaration to hypothesis generation and from hypothesis generation to availability of analytical results were ascertained from peerreviewed publications retrieved by our search. If the intervals were not explicitly stated, estimations were made, where possible, based on the dates reported. The date of commencing an analytical study was assumed to be within one day of hypothesis generation (given an analytical study cannot commence without a hypothesis having been defined). Analytical results were assumed to be available one day following the end of the analytical study period, i.e. the period over

\section{Box}

Inclusion criteria for selection of peer-reviewed publications containing epidemiological outbreak investigations

Inclusion criteria

- European outbreak

- Published since 2003 and outbreak occurring in 2000 or later

- Level 3 outbreak or above (cross-regional, national or international outbreak), according to Public Health England definitions.

- Available in English, French, Spanish, German, Greek or Italian

- Analytical study performed (e.g. case-control or cohort study) which data collection was reported to have occurred and following which results would be available to inform action and control measures. PHE outbreak level definitions were applied to all reviewed outbreaks: judgement of the outbreak level was based on the geographical spread of cases, the involvement of national agencies in the investigation and the potential severity of population impact. In England, PHE local centres are responsible for establishing outbreak control teams and leading investigations that affect their local population, with support from the FES. Investigation into nationwide outbreaks or outbreaks with wider impact or greater severity are led nationally by the National Centre of Disease Surveillance and Control or the FES, working as part of a team with local PHE centres and other agencies as relevant.

Outbreaks of gastroenteritis infections were classified into mild to moderate or severe according to the causative organism. Severe infections were those with a recognised risk of serious long-term complications or death. Hypothesis generation and analytical study time intervals were compared by outbreak level, study design, type of infection and number of cases. The median number of days was calculated for each time interval considered. Pearson's correlation coefficient was calculated for the association between the number of cases identified and time intervals within the investigation.

The search and analysis of papers was carried out by one researcher (EV) with regular communications with both co-authors to discuss assumptions and categorisation of studies. Where more than one study related to the same outbreak, the investigation that gave a more complete overview (i.e. more cases) was selected for inclusion.

\section{Results}

The search yielded 1,522 publications, which were reduced to 1,208 following removal of duplicates. After a review of the abstracts, 290 full-text papers were selected for further screening. Application of the inclusion and exclusion criteria led to 86 studies being

TABLE 1

Public Health England incident levels

\begin{tabular}{|l|l|l|}
\hline Level & Description & Authority to assign response level \\
\hline 1 & Local with limited public health impact. & $\begin{array}{l}\text { Public Health England (PHE) Centre Director/Leader of Local Health } \\
\text { Protection Service }\end{array}$ \\
\hline 2 & $\begin{array}{l}\text { Local with limited public health impact but greater than } \\
\text { can be managed by one PHE centre. }\end{array}$ & $\begin{array}{l}\text { PHE Regional Director (in consultation with the Director for Health } \\
\text { Protection if appropriate) }\end{array}$ \\
\hline 3 & $\begin{array}{l}\text { Public health impact across regional boundaries or } \\
\text { national. May require national coordination. }\end{array}$ & $\begin{array}{l}\text { PHE Director of Health Protection and/or Duty Director in consultation } \\
\text { with the Chief Operating Officer (COO) }\end{array}$ \\
\hline 4 & $\begin{array}{l}\text { Public health impact severe. Requires central direction and } \\
\text { formal interaction with the Government. }\end{array}$ & $\begin{array}{l}\text { PHE Director for Health Protection in consultation with Chief } \\
\text { Executive Officer (CEO) and/or Duty Director and COO }\end{array}$ \\
\hline 5 & $\begin{array}{l}\text { Public health impact catastrophic. Requires central } \\
\text { direction and extensive commitment of resources. }\end{array}$ & PHE CEO and/or Duty Director \\
\hline
\end{tabular}

Source: [3]. 
selected for this review [4-89]. Of the selected results, 63 were classed as level 3 outbreaks, 22 level 4 and one level 5 . Given the small number of level 5 outbreaks, these were combined with level 4 outbreaks for the analysis.

\section{Distribution by country}

The countries with the highest number of outbreaks, with peer-reviewed reports meeting the inclusion criteria were the United Kingdom (UK), Germany and the Netherlands (Table 2).

A total of 19 outbreaks occurred across the UK (eight across two or more countries within the UK, four in Scotland, three in England, three in Wales and one in Northern Ireland). These were led by the Health Protection Agency (now Public Health England), Health Protection Scotland, the National Health Protection Service for Wales and the Communicable Disease Surveillance Centre for Northern Ireland, as appropriate.

Germany was the location of the level 5 outbreak investigation that was reviewed, which related to an outbreak of Escherichia coli 0104 infection in May 2011 [22]. Investigations of outbreaks in Germany were all led by the Robert Koch Institute. All investigations of outbreaks occurring in the Netherlands were supported or led by the Dutch National Institute for Public Health and Environment (RIVM).

\section{Reporting of time intervals}

Date of outbreak declaration was reported in 75 papers and at least one time interval was available from 55 of the 86 included papers. The hypothesis generation interval was more frequently available ( 50 papers) than the analytical study interval (28 papers). Of the 50 studies providing the hypothesis generation interval,
26 also included the analytical study period. Both intervals were available from nine of the 23 level 4 and 5 outbreaks and from 17 of the 63 level 3 outbreak investigations. A further two studies only reported the interval from hypothesis generation to availability of analytical results and three studies only reported the total time from outbreak declaration to availability of analytical results.

\section{Time intervals by outbreak level}

The median hypothesis generation and analytical study time intervals were shorter in level 4 and 5 outbreaks (median: 3 days; range: 1-21 and median: 7 days; range: 1-26 respectively) compared with level 3 outbreaks (median: 12 days; range: 1-168 and median: 19 days; range: 7-59 respectively). Overall, analytical results for level 4 and 5 outbreaks tended to be available around two weeks following the outbreak declaration (median: 15 days; range: 4-32), with 20 of 22 completed within 28 days. Analytical results for level 3 outbreaks tended to be available around a month following outbreak declaration (median: 31 days; range: 9-213) and 9 of 10 were completed within 65 days (Figure, Table 3).

\section{Time intervals by study design}

The most common study design was a case-control study $(n=52)$. The proportion of case-control studies by outbreak level was similar in level 3 (38 of 63) and level 4 and 5 outbreaks (14 of 23). Approximately a third $(n=18)$ of all case-control studies reported using matched controls. Cohort studies were carried out in 26 of the selected papers, with similar proportions across outbreak levels (19 of 63 level 3 and 7 of 23 levels 4 and 5). The median interval from outbreak declaration to hypothesis generation was shorter in level 4 and 5 outbreaks than in level 3 outbreaks, and the total investigation period (from outbreak investigation

\section{TABLE 2}

Number of selected papers, by country and outbreak level, in peer-reviewed publications containing epidemiological outbreak investigations $(\mathrm{n}=86)$

\begin{tabular}{|c|c|c|c|c|c|}
\hline \multirow[b]{2}{*}{ Country of outbreak } & \multicolumn{2}{|r|}{ Level $3^{\mathrm{a}}$} & \multicolumn{2}{|c|}{ Levels 4 and $5^{b}$} & \multirow{2}{*}{$\begin{array}{c}\text { Number of } \\
\text { papers }\end{array}$} \\
\hline & $\begin{array}{c}\text { Number of } \\
\text { papers }\end{array}$ & Source & $\begin{array}{l}\text { Number of } \\
\text { papers }\end{array}$ & Source & \\
\hline United Kingdom & 14 & {$[4-6,9-11,14-21]$} & 5 & {$[7,8,12,13,72]$} & 19 \\
\hline Germany & 11 & {$[24-31,33,35,89]$} & 3 & {$[22,32,34]$} & 14 \\
\hline The Netherlands & 8 & [36-43] & 2 & {$[44,45]$} & 10 \\
\hline France & 6 & {$[59,69,78,79,81,84]$} & 2 & {$[51,58]$} & 8 \\
\hline Norway & 6 & {$[48,61,64,67,77,85]$} & 1 & [53] & 7 \\
\hline Italy & 5 & {$[62,76,80,82,83]$} & 1 & [49] & 6 \\
\hline Denmark & 4 & {$[23,57,63,70]$} & 1 & [50] & 5 \\
\hline Spain & 1 & [52] & 2 & {$[65,73]$} & 3 \\
\hline Sweden & 1 & [46] & 2 & {$[47,75]$} & 3 \\
\hline Other European countries & 7 & {$[54,56,60,66,68,86,88]$} & 4 & {$[55,71,74,87]$} & 11 \\
\hline Total number of papers selected & 63 & - & 23 & - & 86 \\
\hline
\end{tabular}

a Cross-regional or national impact with national coordination.

${ }^{b}$ National or international outbreak with potentially severe or catastrophic public health impact requiring national direction. 
to availability of analytical results) was shorter in cohort studies than in case-control studies (Table 4). Unfortunately, however, the number of outbreaks reporting time intervals by study design was too small to make robust comparisons.

A small number of studies used other study designs, including case-case [44] and case series [16], or a combined approach of case-control and cohort $[11,18,28,33,46,47]$. One level 4 outbreak used a mixed case-control and cohort design [47]. This investigation was of a large-scale outbreak of $E$. coli infection with 135 linked cases and was completed around a week from outbreak declaration. The speed of this investigation is likely to have been aided by mandatory surveillance information gathered on cases in the two months before recognition of the scale of the outbreak, when a rise in the number of cases had been noted but no common source or E. coli subtype identified. Environmental samples were also pivotal in the testing of the hypothesis and prompt withdrawal of the implicated product from the market.

\section{Time intervals by type of infection}

The majority of papers $(n=65)$ related to outbreaks of gastroenteritis. Where such outbreaks were suspected or known to be due to more severe infections (i.e. verotoxin-producing E. coli (VTEC), Shiga toxin-producing E. coli (STEC), Shigella sonnei), investigations appear to have been completed more rapidly than mild to moderate infections. The median investigation period (from outbreak declaration to availability of analytical results) for level 3 outbreaks of mild to moderate gastroenteritis was 31 days, compared with 10 days for level 4 and 5 outbreaks of severe gastroenteritis (Table 4).

\section{FIGURE}

Time intervals of outbreak investigations by outbreak level in selected peer-reviewed publications containing epidemiological outbreak investigations $(n=55)$

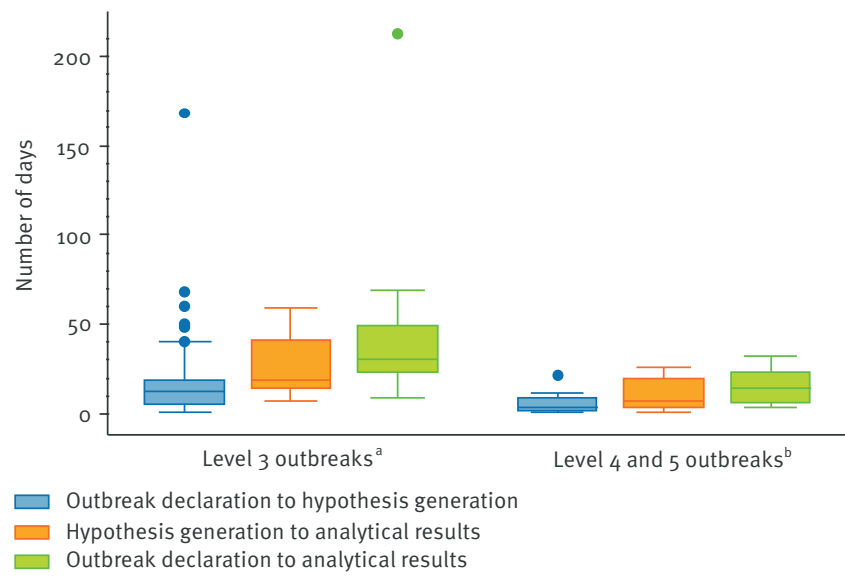

Boxes represent the interquartile range (IQR) and the median. Whiskers incorporate values within 1.5 times the IQR from quartile 1 and 3 (Q1 and $\left.Q_{3}\right)$. Where maximum and minimum values lie within $\mathrm{Q}_{3}+1.5 \times \mathrm{IQR}$ or $\mathrm{Q}_{1}-1.5 \times \mathrm{IQR}$, the end of the whiskers represent the maximum and minimum values.

Outliers are less than $Q_{1}-1.5 \times I Q R$ or greater than $3+1.5 \times I Q R$ and are represented by dots.

a Cross-regional or national public health impact with national coordination.

b National or international outbreak with potentially severe or catastrophic public health impact requiring national direction.

\section{TABLE 3}

Time intervals of outbreak investigations by outbreak level in selected peer-reviewed publications containing epidemiological outbreak investigations $(\mathrm{n}=55)$

\begin{tabular}{|c|c|c|c|c|c|c|c|c|}
\hline \multirow[b]{3}{*}{ Time interval } & \multicolumn{8}{|c|}{ Outbreak level } \\
\hline & \multicolumn{3}{|c|}{$\begin{array}{c}3^{a} \\
n=63\end{array}$} & \multicolumn{3}{|c|}{$\begin{array}{c}4 \text { and } 5^{b} \\
n=23\end{array}$} & \multicolumn{2}{|c|}{$\begin{array}{c}\text { Total ( } 3 \text { to } 5) \\
n=86\end{array}$} \\
\hline & $\begin{array}{l}\text { Number } \\
\text { of papers } \\
\text { reporting } \\
\text { interval }\end{array}$ & Source & $\begin{array}{l}\text { Median } \\
\text { number } \\
\text { of days } \\
\text { (range) }\end{array}$ & $\begin{array}{l}\text { Number } \\
\text { of papers } \\
\text { reporting } \\
\text { interval }\end{array}$ & Source & $\begin{array}{l}\text { Median } \\
\text { number } \\
\text { of days } \\
\text { (range) }\end{array}$ & $\begin{array}{l}\text { Number } \\
\text { of papers } \\
\text { reporting } \\
\text { interval }\end{array}$ & $\begin{array}{l}\text { Median } \\
\text { number } \\
\text { of days } \\
\text { (range) }\end{array}$ \\
\hline $\begin{array}{l}\text { Between } \\
\text { hypothesis } \\
\text { generation and } \\
\text { availability of } \\
\text { analytical results }\end{array}$ & 19 & $\begin{array}{c}{[6,9,11,17,18,20,21} \\
23,25,29-31 \\
37,38,42,52,54,56,57]\end{array}$ & $19(7-59)$ & 9 & $\begin{array}{c}{[7,8,22,45,47} \\
49,50,53,55]\end{array}$ & $7(1-26)$ & 28 & $15(1-59)$ \\
\hline $\begin{array}{l}\text { Between outbreak } \\
\text { declaration and } \\
\text { availability of } \\
\text { analytical results }\end{array}$ & 22 & $\begin{array}{c}{[5,6,9,11,17,18,20,21} \\
23,25,29-31,36-38 \\
42,43,52,54,56,57]\end{array}$ & $31(9-213)$ & 10 & $\begin{array}{c}{[7,8,22,45,47} \\
49-51,53,55]\end{array}$ & $15(4-32)$ & 32 & $\begin{array}{c}28 \\
(4-213)\end{array}$ \\
\hline
\end{tabular}

${ }^{\text {a }}$ Cross-regional or national public health impact with national coordination.

${ }^{b}$ National or international outbreak with potentially severe or catastrophic public health impact requiring national direction. 


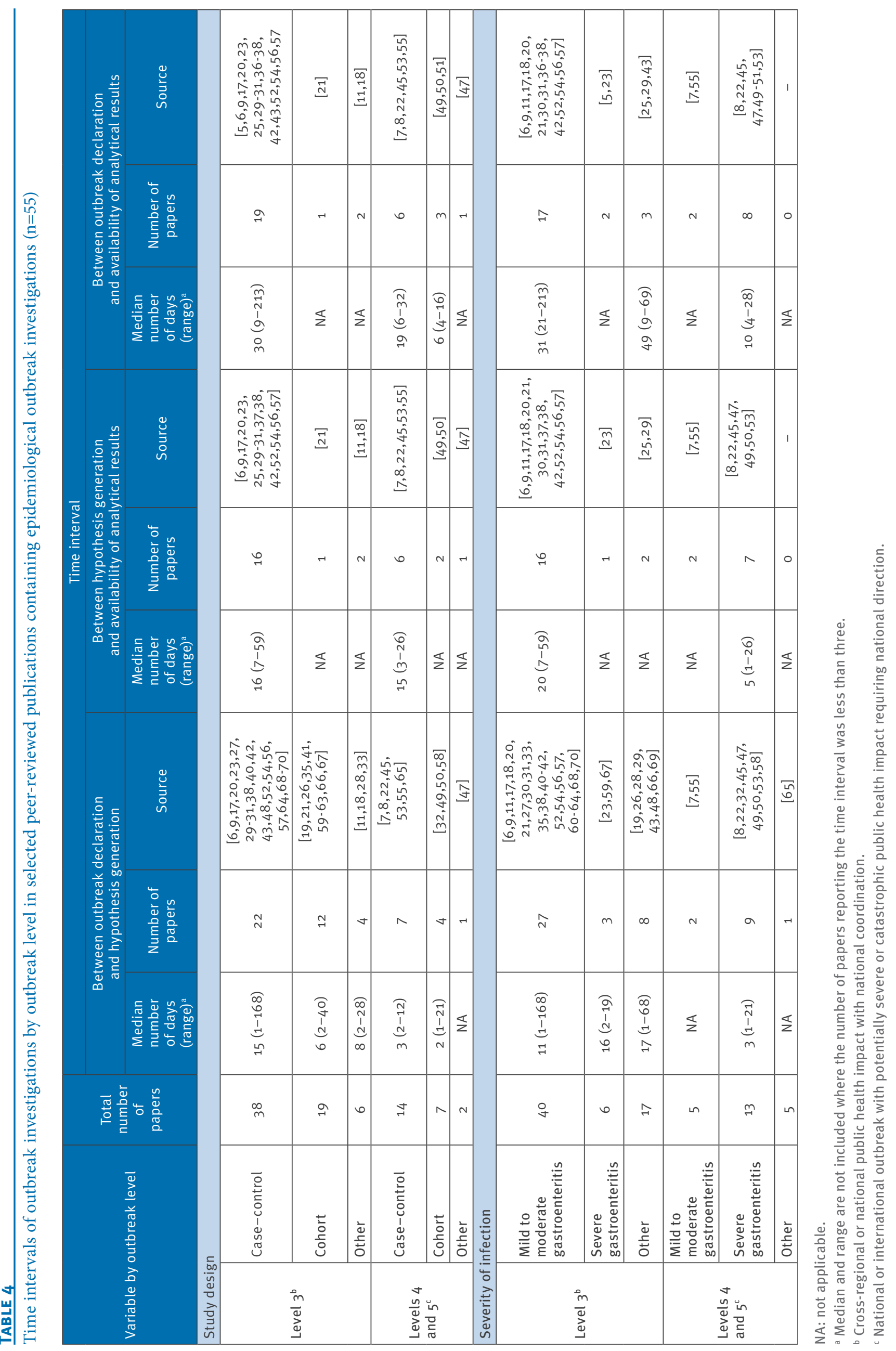


The time it takes to complete an epidemiological investigation may in part be affected by the natural history of infectious diseases, namely the incubation period. Where incubation periods are longer, it will take longer for cases to be detected, given the longer period until symptoms develop in exposed individuals, and there is therefore an increased risk of recall bias. This may lead to delays in the identification of the source of an outbreak and may present greater challenges in identifying additional linked cases, given the increased potential for the movement of cases. Unfortunately, the number of studies of non-gastroenteritis outbreaks in this review was relatively small $(n=22)$ and with few of them reporting time intervals $(n=9)$, it was difficult to identify patterns related to specific infections or incubation periods.

In this review, level 4 and 5 outbreak investigations, with time intervals reported, included infections of STEC, VTEC, Shigella sonnei, Salmonella and hepatitis A. Level 3 reports, with time-intervals reported, included infections of E. coli, Cryptosporidium parvum, Campylobacter, Giardia lamblia, hepatitis A, Legionella pneumophila, Leptospira, norovirus, Pseudomonas aeruginosa, Salmonella, meningitis due to echovirus or coxsackievirus, Coxiella burnetii and Yersinia pseudotuberculosis. Only one report of a nosocomial outbreak was included in this review (due to $P$. aeruginosa infection) [48]. This nosocomial outbreak took 68 days from outbreak declaration to form a hypothesis and no other time intervals were reported.

\section{Time intervals and number of cases}

There was no correlation between the number of suspected and confirmed cases reported in an outbreak and the number of days from outbreak declaration to hypothesis generation $\left(r^{2}=0.0007\right)$. There was also no correlation between the number of cases and the number of days to completion an analytical report $\left(r^{2}=0.00001\right)$.

\section{Discussion}

This review found considerable variation in the speed of generating a hypothesis and obtaining analytical results following declaration of an outbreak with cross-regional, national or international public health impacts. The analytical study period following declaration of an outbreak tended to be shorter for outbreaks classified as level 4 or 5 . This is likely to be due to a greater amount of resources being quickly mobilised following identification of an outbreak of this nature. By definition, such outbreaks are deemed to have the potential for severe or catastrophic public health impact and direction by national agencies will bring with it the ability to command greater resource deployment.

It should also be noted that the categorisation of outbreak level was based on definitions used by PHE and applied to outbreaks across Europe. Countries outside England may use different criteria to assess the potential impact of an outbreak, which may affect the level of response and timeliness of investigations. Therefore, conclusions regarding the timeliness of outbreak investigations by level should be drawn with caution.

The outbreak investigation period, which has a major influence on the timeliness of controlling an infectious disease outbreak, is just one part of a bigger picture. Whether an investigation period of 15 days for levels 4 and 5 and 31 days for level 3 from outbreak declaration to the availability of analytical results is acceptable needs to be considered alongside delays in outbreak recognition and notification, as well as how swiftly the required control measures are implemented following availability of the analytical results; all of which will affect the resulting population impact.

The study design appears to be one factor influencing the speed of completing analytical investigations; however, choice of study design is likely to be limited by the context of the outbreak. The longer time intervals in case-control studies may be due to challenges of identifying cases speedily and difficulties in selecting and recruiting appropriate controls. Hypothesis generation in cohort studies is likely to be swifter given the investigation starts with an identified population cohort. The factor that identifies the group as a cohort will itself provide clues to the source of the outbreak. In contrast, case-control studies often involve the identification of additional cases over time, which is likely to increase the time taken to define a hypothesis. While control selection methods for such studies was outside the focus of this review, some points are worth noting. Details of control selection methods were often lacking or sparse in the reviewed outbreak reports. Random digit dialling within specific postcode districts or other geographical areas was used in a number of investigations for which analytical results were available within three weeks of the outbreak being declared $[6,20,25]$. In one investigation, which was completed in 22 days, cases were asked to nominate a number of controls (given relevant criteria) [9]. A detailed description of control selection methods used by researchers at RIVM in the Netherlands was provided by Whelan et. al. [38] in a report of a level 3 case-control study, which had an analytical study period of 16 days (the median for this level in our analysis). RIVM receives each year a randomly selected list of 500 residents from each municipality (based on a unique reference number), totalling about 20,000 individuals per year. From this, a simple random sample of 300-500 individuals are invited to take part in an annual 36-question survey. The survey covers demographics, symptoms, travel history and risk factors in the previous 30 days. Completed surveys are used for enhanced surveillance of food-borne and respiratory infections and can be used in outbreak investigations, reducing the reliance on additional manpower for control selection and interviews [38]. 
The number of cases may be considered an important factor in the speed of completing epidemiological investigations, both in terms of the public health importance of a large outbreak necessitating a speedy response, and the amount of information available from trawling interviews on which to base hypotheses. However, no association was found between the number of cases detected and the speed of completing an epidemiological investigation among the studies included in this review. A longer delay in detecting an outbreak is likely to lead to a higher number of cases and a greater risk of an outbreak escalating to a higher level. Unfortunately, delayed recognition of outbreaks could not be analysed in this review as any difference between the date the number of cases in the population reached outbreak levels and the date an outbreak was recognised and declared by authorities was rarely reported.

There will be additional factors influencing the timeliness of analytical epidemiological investigations that were not available from the published reports in this review, such as the local public health systems, the availability of resources for investigations, the quality of surveillance and effective public communications. The severe acute respiratory syndrome (SARS) outbreak in 2003 heightened governmental awareness of the risks and impacts of international outbreaks in the context of increased global travel; the timeliness of investigations and public communications appears to have improved somewhat since [90]. The use of electronic surveillance systems and algorithms to detect outbreaks has also improved the detection of outbreaks and the subsequent public health response in a number of countries [91-93]. Such surveillance systems should be regularly evaluated in order to ensure their ongoing usefulness and contribution to timely outbreak investigations [93]. In addition to effective, responsive surveillance systems, public communications regarding specific outbreaks can assist both in detecting outbreaks and in reducing the number of additional cases.

Publication bias is likely to have affected the findings of this study; not all languages were included in the review and there is likely to be a bias towards publishing reports where a source was identified. This may in part account for the large proportion of gastroenteritis outbreak investigations in this review; the short incubation times of these infections may reduce recall bias, leading to more reliable information on which to identify the source of the outbreak. There may also be some bias towards publication of swifter investigations that are considered unusual or highlight good practice. A previous review of published and unpublished food-borne gastroenteritis outbreaks found that few outbreaks reported to the Health Protection Agency (now Public Health England) led to peer-reviewed publication; those that were published had a bias towards more unusual outbreaks [94]. Therefore, a review of time periods within unpublished outbreak investigations would complement this report. It would also be interesting for future studies to compare the timeliness of investigations with identification of a source and implementation of robust control measures.

Timeliness in outbreak investigations is important for minimising the number of people affected and protecting public health. Our findings provide a first overview of timeliness of analytical outbreak investigations. Given the current lack of guidance, it will be useful to develop guidelines regarding what might be considered timely and how to improve the timeliness of outbreak investigations.

A key finding from this review is the need for more standardised reporting of time intervals in outbreak investigations so that the timeliness of investigations can be better understood. This will be required before firmer performance-monitoring standards can be developed. Our results suggest separate guidance and/or standards for the completion of analytical studies according to the severity of public health impact could be established.

While this review has provided useful material to inform discussions within PHE as to what might be considered as high quality in terms of timeliness, organisations within other countries may also find our results useful when considering factors influencing the speed of outbreak investigations and service improvements to ensure prompt completion of investigations. Separate recommendations for intervals from outbreak declaration to hypothesis generation and from hypothesis generation to completion of an epidemiological investigation could be considered; however, the number of studies reporting separate intervals is too small and the variation in timeliness too wide to draw firm conclusions from this review. The development of standards for performance monitoring requires further consideration. Such standards may assist investigation teams in getting organisational support for mobilisation of resources and lead to a more rapid public heath response. However, flexibility in applying standards to monitor the effectiveness of and improvements in outbreak investigations is advisable to allow for variation in the context and complexity of an outbreak. The introduction of such guidance or standards may usefully be accompanied by the development of tools to support prompt investigations. Robust routine surveillance systems and workforce capacity must also be maintained to enable prompt recognition of and response to outbreaks.

\section{Acknowledgments}

We would like to thank Maya Gobin, Regional Epidemiologist at Public Health England and Lars Schaande, Vice President, and Professor Dr Reinhard Burger, President of the Robert Koch Institute, for their communications and contributions to this study.

The research was funded by the National Institute for Health Research Health Protection Research Unit (NIHR HPRU) in Evaluation of Interventions at the University of Bristol in partnership with Public Health England. 
Conflict of interest

None declared.

\section{Authors' contributions}

EV led the literature review, data extraction and analysis. All authors contributed to the study design and interpretation of data, all participated in drafting and revising the paper, and all approved the final draft for publication.

\section{References}

1. World Health Organization (WHO). International Health Regulations (2005). 2nd ed. Geneva: WHO; 2008. Available from: http://www.who.int/ihr/9789241596664/en/

2. Health and Social Care Act 2012. London: Her Majesty's Stationery Office; 2012. Available from: http://www. legislation.gov.uk/ukpga/2012/7/contents/enacted

3. Public Health England (PHE). Communicable disease outbreak management: operational guidance. London: PHE: 2014. Available from: https://www.gov.uk/government/publications/ communicable-disease-outbreak-management-operationalguidance

4. Janmohamed K, Zenner D, Little C, Lane C, Wain J, Charlett A, et al. National outbreak of Salmonella Enteritidis phage type 14b in England, September to December 2009: Case-control study. Euro Surveill. 2011;16(15):19840 Available from: http://www. eurosurveillance.org/ViewArticle.aspx?Articleld=1984.

5. Ihekweazu C, Carroll K, Adak B, Smith G, Pritchard GC, Gillespie IA, et al. Large outbreak of verocytotoxinproducing Escherichia coli 0157 infection in visitors to a petting farm in South East England, 2009. Epidemiol Infect. 2012;140(8):1400-13. Available from: http://dx.doi.org/10.1017/ So950268811002111 PMID:22093751

6. Boxall NS, Adak GK. DE Pinna E, Gillespie IA. A Salmonella Typhimurium phage type (PT) U320 outbreak in England, 2008: continuation of a trend involving ready-to-eat products. Epidemiol Infect. 2011;139(12):1936-44. Available from: http:// dx.doi.org/10.1017/S0950268810003080 PMID:21255477

7. Horby PW, O'Brien SJ, Adak GK, Graham C, Hawker JI, Hunter $P$, et al. A national outbreak of multi-resistant Salmonella enterica serovar Typhimurium definitive phage type (DT) 104 associated with consumption of lettuce. Epidemiol Infect. 2003;130(2):169-78. Available from: http://dx.doi.org/10.1017/ So950268802008063 PMID:12729184

8. Whittaker PJ, Sopwith W, Quigley C, Gillespie I, Willshaw GA, Lycett C, et al. A national outbreak of verotoxin-producing Escherichia coli 0157 associated with consumption of lemonand-coriander chicken wraps from a supermarket chain. Epidemiol Infect. 2009;137(3):375-82. Available from: http:// dx.doi.org/10.1017/S0950268808001702 PMID:19102799

9. Irvine WN, Gillespie IA, Smyth FB, Rooney PJ, McClenaghan A, Devine MJ, et al. Investigation of an outbreak of Salmonella enterica serovar Newport infection. Epidemiol Infect. 2009;137(10):1449-56. Available from: http://dx.doi. org/10.1017/S0950268809002416 PMID:19296871

10. Wilson LE, Couper S, Prempeh H, Young D, Pollock KG, Stewart WC, et al. Investigation of a $Q$ fever outbreak in a Scottish co-located slaughterhouse and cutting plant. Zoonoses Public Health. 2010;57(7-8):493-8. Available from: http://dx.doi. org/10.1111/j.1863-2378.2009.01251.x PMID:19912614

11. Cowden J, Hamlet N, Locking M, Allardice G. A national outbreak of infection with Salmonella enteritidis phage types $5 \mathrm{C}$ and $6 \mathrm{a}$ associated with Chinese food businesses in Scotland, summer 2000. Epidemiol Infect. 2003;130(3):387-93. Available from: PMID:12825722

12. McCartney G, Cowden J, Murray S, Ahmed S. The use of a new virtual cohort study design to investigate an outbreak of $E$. coli 0157 linked to a supermarket delicatessen. Epidemiol Infect. 2010:138(10):1439-42. Available from: http://dx.doi. org/10.1017/S0950268810000257 PMID:20144252

13. Palmateer NE, Ramsay CN, Browning L, Goldberg DJ, Hutchinson S]. Anthrax infection among heroin users in Scotland during 2009-2010: a case-control study by linkage to a national drug treatment database. Clin Infect Dis. 2012;55(5):706-10. Available from: http://dx.doi.org/10.1093/ cid/cis511 PMID:22618565

14. Vivancos R, Keenan A, Sopwith W, Smith K, Quigley C, Mutton $\mathrm{K}$, et al. Norovirus outbreak in a cruise ship sailing around the British Isles: investigation and multi-agency management of an international outbreak. J Infect. 2010;60(6):478-85.
Available from: http://dx.doi.org/10.1016/j.jinf.2010.03.018 PMID:20359496

15. Gajraj R, Pooransingh S, Hawker JI, Olowokure B. Multiple outbreaks of Salmonella braenderup associated with consumption of iceberg lettuce. Int J Environ Health Res. 2012;22(2):150-5. Available from: http://dx.doi.org/10.1080/09 603123.2011.613114 PMID:21916661

16. Andersson MI, Low N, Irish CJ, Verlander NQ, Carrington D, Horner P, et al. Investigation of a large community-based outbreak of hepatitis B infection in the United Kingdom. Epidemiol Infect. 2012;140(1):47-57. Available from: http:// dx.doi.org/10.1017/So950268811000148 PMID:21324219

17. Cleary P, Browning L, Coia J, Cowden J, Fox A, Kearney J, et al. A foodborne outbreak of Salmonella Bareilly in the United Kingdom, 2010. Euro Surveill. 2010;15(48):19732 PMID:21144449.

18. Gobin M, Launders N, Lane C, Kafatos G, Adak B. National outbreak of Salmonella Java phage type 3 b variant 9 infection using parallel case-control and case-case study designs, United Kingdom, July to October 2010. Euro Surveill. 2011;16(47):20023. Available from: PMID:22152706

19. van Woerden HC, Mason BW, Nehaul LK, Smith R, Salmon RL, Healy B, et al. Q fever outbreak in industrial setting. Emerg Infect Dis. 2004:10(7):1282-9. Available from: http://dx.doi. org/10.3201/eid1007.030536 PMID:15324550

20. Mason BW, Chalmers RM, Carnicer-Pont D, Casemore DPA A Cryptosporidium hominis outbreak in north-west Wales associated with low oocyst counts in treated drinking water. J Water Health. 2010;8(2):299-310. Available from: http://dx.doi. org/10.2166/wh.2009.184 PMID:20154393

21. Griffiths SL, Salmon RL, Mason BW, Elliott C, Thomas DR, Davies C. Using the internet for rapid investigation of an outbreak of diarrhoeal illness in mountain bikers. Epidemiol Infect. 2010;138(12):1704-11. Available from: http://dx.doi. org/10.1017/S0950268810001561 PMID:20587125

22. Frank C, Faber MS, Askar M, Bernard H, Fruth A, Gilsdorf A, et al. HUS investigation team. Large and ongoing outbreak of haemolytic uraemic syndrome, Germany, May 2011. Euro Surveill. 2011;16(21):19878. Available from: PMID:21632020

23. Jensen C, Ethelberg S, Gervelmeyer A, Nielsen EM, Olsen KE, Mølbak K, et al. First general outbreak of Verocytotoxinproducing Escherichia coli 0157 in Denmark. Euro Surveill. 11(2): 6;11(2):pii=597. Available from: http://www. eurosurveillance.org/ViewArticle.aspx?Articleld=597. PMID: 16525198

24. Alpers K, Werber D, Frank C, Koch J, Friedrich AW, Karch H, et al. Sorbitol-fermenting enterohaemorrhagic Escherichia coli $0157: \mathrm{H}$ - causes another outbreak of haemolytic uraemic syndrome in children. Epidemiol Infect. 2009;137(3):389-95. Available from: http://dx.doi.org/10.1017/S0950268808001465 PMID:19021923

25. Schenkel K, Bremer V, Grabe C, Van Treeck U, Schreier E, Höhne M, et al. Outbreak of hepatitis A in two federal states of Germany: bakery products as vehicle of infection. Epidemiol Infect. 2006;134(6):1292-8. Available from: http://dx.doi. org/10.1017/S0950268806006212 PMID:16650329

26. Desai S, van Treeck U, Lierz M, Espelage W, Zota L, Sarbu A, et al. Resurgence of field fever in a temperate country: an epidemic of leptospirosis among seasonal strawberry harvesters in Germany in 2007. Clin Infect Dis. 2009;48(6):6917. Available from: http://dx.doi.org/10.1086/597036 PMID:19193108

27. Stöcker P, Rosner B, Werber D, Kirchner M, Reinecke A, Wichmann-Schauer H, et al. Outbreak of Salmonella Montevideo associated with a dietary food supplement flagged in the Rapid Alert System for Food and Feed (RASFF) in Germany, 2010. Euro Surveill. 2011;16(50):20040. Available from: PMID:22221497

28. Porten K, Rissland J, Tigges A, Broll S, Hopp W, Lunemann M, et al. A super-spreading ewe infects hundreds with $Q$ fever at a farmers' market in Germany. BMC Infect Dis. 2006;6(1):147. Available from: http://dx.doi.org/10.1186/1471-2334-6-147 PMID:17026751

29. Hauri AM, Schimmelpfennig M, Walter-Domes M, Letz A, Diedrich S, Lopez-Pila J, et al. An outbreak of viral meningitis associated with a public swimming pond. Epidemiol Infect. 2005;133(2):291-8. Available from: http://dx.doi.org/10.1017/ So950268804003437 PMID:15816154

30. Bremer V, Leitmeyer K, Jensen E, Metzel U, Meczulat H, Weise $\mathrm{E}$, et al. Outbreak of Salmonella Goldcoast infections linked to consumption of fermented sausage, Germany 2001. Epidemiol Infect. 2004;132(5):881-7. Available from: http://dx.doi. org/10.1017/So950268804002699 PMID:15473151

31. Werber D, Dreesman J, Feil F, van Treeck U, Fell G, Ethelberg S, et al. International outbreak of Salmonella Oranienburg due to 
German chocolate. BMC Infect Dis. 2005;5:7. Available from: http://dx.doi.org/10.1186/1471-2334-5-7 PMID:15691371

32. Scharlach M, Diercke M, Dreesman J, Jahn N, Krieck M, Beyrer $\mathrm{K}$, et al. Epidemiological analysis of a cluster within the outbreak of Shiga toxin-producing Escherichia coli serotype 0104: 44 in Northern Germany, 2011. Int J Hyg Environ Health. 2013;216(3):341-5. Available from: http://dx.doi.org/10.1016/j. ijheh.2012.10.001 PMID:23154087

33. Buchholz U, Brodhun B, Brockmann SO, Dreweck CM, Prager $\mathrm{R}$, Tschäpe $\mathrm{H}$, et al. An outbreak of Salmonella München in Germany associated with raw pork meat. J Food Prot. 2005;68(2):273-6. Available from: PMID:15726968

34. Beyrer K, Lai S, Dreesman J, Lee JV, Joseph C, Harrison T, et al. Legionnaires' disease outbreak associated with a cruise liner, August 2003: epidemiological and microbiological findings. Epidemiol Infect. 2007;135(5):802-10. Available from: http:// dx.doi.org/10.1017/S0950268806007473 PMID:17109773

35. Visser H, Verhoef L, Schop W, Götz HM. Outbreak investigation in two groups of coach passengers with gastroenteritis returning from Germany to the Netherlands in February 2009. Euro Surveill. 2010;15(28):19615. Available from: PMID:20650052

36. Friesema IH, de Jong AE, Fitz James IA, Heck ME, van den Kerkhof JH, Notermans DW, et al. Outbreak of Salmonella Thompson in the Netherlands since July 2012. Euro Surveill. 2012;17(43):20303. Available from: http://www. eurosurveillance.org/ViewArticle.aspx?Articleld =20303

37. Noël $H$, Hofhuis $A$, De Jonge $R$, Heuvelink AE, De Jong A, Heck $M E O C$, et al. Consumption of fresh fruit juice: how a healthy food practice caused a national outbreak of Salmonella Panama gastroenteritis. Foodborne Pathog Dis. 2010;7(4):37581. Available from: http://dx.doi.org/10.1089/fpd.2009.0330 PMID:19909088

38. Whelan J, Noel H, Friesema I, Hofhuis A, de Jager CM, Heck M, et al. National outbreak of Salmonella Typhimurium (Dutch) phage-type 132 in the Netherlands, October to December 2009. Euro Surveill. 2010;15(44):19705. Available from: PMID:21087587

39. Kivi M, Hofhuis A, Notermans DW, Wannet WJ, Heck ME, Van De Giessen AW, et al. A beef-associated outbreak of Salmonella Typhimurium DT104 in The Netherlands with implications for national and international policy. Epidemiol Infect. 2007;135(6):890-9. Available from: http://dx.doi.org/10.1017/ So950268807007972 PMID:17326850

40. Friesema IHM, Schimmer B, Ros JA, Ober HJ, Heck MEOC, Swaan CM, et al. A regional Salmonella enterica serovar Typhimurium outbreak associated with raw beef products, The Netherlands, 2010. Foodborne Pathog Dis. 2012;9(2):1027. Available from: http://dx.doi.org/10.1089/fpd.2011.0978 PMID:22047057

41. Verhoef L, Boxman IL, Duizer E, Rutjes SA, Vennema $H$, Friesema IH, et al. Multiple exposures during a norovirus outbreak on a river-cruise sailing through Europe, 2006. Euro Surveill. 2006;13(24):18899. Available from: http://www. eurosurveillance.org/ViewArticle.aspx?Articleld=18899 PMID: 18761943

42. Van Duynhoven YTHP, Isken LD, Borgen K, Besselse $M$, Soethoudt K, Haitsma O, et al. A prolonged outbreak of Salmonella Typhimurium infection related to an uncommon vehicle: hard cheese made from raw milk. Epidemiol Infect. 2009;137(11):1548-57. Available from: http://dx.doi. org/10.1017/S0950268809002337 PMID:19296867

43. Petrignani M, Harms M, Verhoef L, van Hunen R, Swaan C, van Steenbergen J, et al. Update: a food-borne outbreak of hepatitis A in the Netherlands related to semi-dried tomatoes in oil, January-February 2010. Euro Surveill. 2010;15(20):19572. Available from: PMID:20504389

44. Greenland K, de Jager C, Heuvelink A, van der Zwaluw K, Heck $M$, Notermans D, et al. Nationwide outbreak of STEC O157 infection in the Netherlands, December 2008-January 2009: continuous risk of consuming raw beef products. Euro Surveill. 2009;14(8):19129. Available from: http://www. eurosurveillance.org/ViewArticle.aspx?Articleld=19129 PMID: 19250626

45. Doorduyn Y, de Jager CM, van der Zwaluw WK, Friesema IH, Heuvelink AE, de Boer E, et al. Shiga toxin-producing Escherichia coli (STEC) 0157 outbreak, The Netherlands, September-October 2005. Euro Surveill. 2006;11(7):636. Available from: PMID: 16966799

46. Martin S, Penttinen P, Hedin G, Ljungström M, Allestam $\mathrm{G}$, Andersson $\mathrm{Y}$, et al. A case-cohort study to investigate concomitant waterborne outbreaks of Campylobacter and gastroenteritis in Söderhamn, Sweden, 2002-3. J Water Health. 2006;4(4):417-24. Available from: PMID:17176812

47. Söderström A, Osterberg P, Lindqvist A, Jönsson B, Lindberg A, Blide Ulander S, et al. A large Escherichia coli 0157 outbreak in
Sweden associated with locally produced lettuce. Foodborne Pathog Dis. 2008;5(3):339-49. Available from: http://dx.doi. org/10.1089/fpd.2007.0065 PMID:18767979

48. Iversen BG, Jacobsen T, Eriksen HM, Bukholm G, Melby KK, Nygård K, et al. An outbreak of Pseudomonas aeruginosa infection caused by contaminated mouth swabs. Clin Infect Dis. 2007;44(6):794-801. Available from: http://dx.doi. org/10.1086/511644 PMID:17304450

49. Busani L, Boccia D, Caprioli A, Ruggeri FM, Morabito S, Minelli $F$, et al. Public health implications of a case of haemolyticuraemic syndrome associated with a concomitant outbreak of mild gastroenteritis in a small rural community. Epidemiol Infect. 2006;134(2):407-13. Available from: http://dx.doi. org/10.1017/So950268805004735 PMID:16490147

50. Lewis HC, Ethelberg S, Olsen KEP, Nielsen EM, Lisby M, Madsen SB, et al. Outbreaks of Shigella sonnei infections in Denmark and Australia linked to consumption of imported raw baby corn. Epidemiol Infect. 2009;137(3):326-34. Available from: http://dx.doi.org/10.1017/S0950268808001829 PMID:19134229

51. Duffell E, Espié E, Nichols T, Adak GK, De Valk H, Anderson K, et al. Investigation of an outbreak of E. coli 0157 infections associated with a trip to France of schoolchildren from Somerset, England. Euro Surveill. 2003;8(4):406. Available from: PMID:12764237

52. Rodriguez-Urrego J, Herrera-Leon S, Echeita-Sarriondia A, Soler P, Simon F, Mateo S, et al. Nationwide outbreak of Salmonella serotype Kedougou associated with infant formula, Spain, 2008. Euro Surveill. 2010;15(22):19582. Available from: PMID:20546688

53. Schimmer B, Nygard K, Eriksen HM, Lassen J, Lindstedt BA, Brandal LT, et al. Outbreak of haemolytic uraemic syndrome in Norway caused by stx2-positive Escherichia coli $0_{103}: \mathrm{H}_{2} 5$ traced to cured mutton sausages. BMC Infect Dis. 2008;8(1):41. Available from: http://dx.doi.org/10.1186/1471-2334-8-41 PMID:18387178

54. Pastore R, Schmid H, Altpeter E, Baumgartner A, Hächler $\mathrm{H}$, Imhof R, et al. Outbreak of Salmonella serovar Stanley infections in Switzerland linked to locally produced soft cheese, September 2006 - February 2007. Euro Surveill. 2008;13(37):18979. Available from: PMID:18801315

55. Nicolay N, Thornton L, Cotter S, Garvey P, Bannon O, McKeown $P$, et al. Salmonella enterica serovar Agona European outbreak associated with a food company. Epidemiol Infect. 2011;139(8):1272-80. Available from: http://dx.doi.org/10.1017/ So950268810002360 PMID:20950515

56. Werber D, Lausević D, Mugosa B, Vratnica Z, Ivanović-Nikolić L, Zizić L, et al. Massive outbreak of viral gastroenteritis associated with consumption of municipal drinking water in a European capital city. Epidemiol Infect. 2009;137(12):1713-20. Available from: http://dx.doi.org/10.1017/S095026880999015X PMID:19534843

57. Wójcik OP, Kjelsø C, Kuhn KG, Müller L, Jensen T, Kjeldsen MK, et al. Salmonella Typhimurium outbreak associated with smoked pork tenderloin in Denmark, January to March 2011. Scand I Infect Dis. 2012;44(12):903-8. Available from: http:// dx.doi.org/10.3109/00365548.2012.693196 PMID:22804453

58. Gault G, Weill FX. Mariani-Kurkdjian, Jourdan-da Silva N, King $\mathrm{L}$, Aldabe B, et al. Outbreak of haemolytic uraemic syndrome and bloody diarrhoea due to Escherichia coli $\mathrm{O}_{104}: \mathrm{H}_{4}$, southwest France, June 2011. Euro Surveill. 2011;16(26):19905 Available from: http://www.eurosurveillance.org/ViewArticle. aspx?Articleld=19905 PMID: 21749817.

59. King LA, Nogareda F, Weill FX, Mariani-Kurkdjian P, Loukiadis E, Gault G, et al. Outbreak of Shiga toxin-producing Escherichia coli 0104: $\mathrm{H}_{4}$ associated with organic fenugreek sprouts, France, June 2011. Clin Infect Dis. 2012;54(11):1588-94. PMID 22460976

6o. Pedalino B, Feely E, McKeown P, Foley B, Smyth B, Moren A. An outbreak of Norwalk-like viral gastroenteritis in holidaymakers travelling to Andorra, January-February 2002. Euro Surveill. 2003;8(1):393. Available from: PMID:12631977

61. Jakopanec I, Borgen K, Vold L, Lund H, Forseth T, Hannula $\mathrm{R}$, et al. A large waterborne outbreak of campylobacteriosis in Norway: the need to focus on distribution system safety. BMC Infect Dis. 2008;8(1):128. Available from: http://dx.doi. org/10.1186/1471-2334-8-128 PMID:18816387

62. Prato R, Lopalco PL, Chironna M, Barbuti G, Germinario C, Quarto M. Norovirus gastroenteritis general outbreak associated with raw shellfish consumption in south Italy. BMC Infect Dis. 2004;4(1):37. Available from: http://dx.doi. org/10.1186/1471-2334-4-37 PMID:15383150

63. Mazick A, Ethelberg S, Nielsen EM, Mølbak K, Lisby M. An outbreak of Campylobacter jejuni associated with consumption of chicken, Copenhagen, 2005. Euro Surveill. 2006;11(5):622. Available from: PMID:16757851 
64. Nygård K, Schimmer B, Søbstad $\varnothing$, Walde A, Tveit I, Langeland $\mathrm{N}$, et al. A large community outbreak of waterborne giardiasisdelayed detection in a non-endemic urban area. BMC Public Health. 2006;6(1):141. Available from: http://dx.doi. org/10.1186/1471-2458-6-141 PMID:16725025

65. Ortega-Maján MT, Caffaro-Rovira M, Herrera-Guibert DJ, RivasPérez A. (Detection of a hepatitis A outbreak in Ceuta (Spain) through a microbiological surveillance system). Gac Sanit. 2008;22(4):382-4. Available from: Spanish. PMID:18755092

66. Rimhanen-Finne R, Niskanen T, Hallanvuo S, Makary P, Haukka $\mathrm{K}$, Pajunen S, et al. Yersinia pseudotuberculosis causing a large outbreak associated with carrots in Finland, 2006. Epidemiol Infect. 2009;137(3):342-7. Available from: http:// dx.doi.org/10.1017/S0950268807000155 PMID:18177523

67. Møller-Stray J, Eriksen HM, Bruheim T, Kapperud G, Lindstedt $B A$, Skeie $\AA$, et al. Two outbreaks of diarrhoea in nurseries in Norway after farm visits, April to May 2009. Euro Surveill. 2012;17(47):20321. Available from: PMID:23231858

68. Horváth JK, Mengel M, Krisztalovics K, Nogrady N, Pászti J, Lenglet $A$, et al. Investigation into an unusual increase of human cases of Salmonella Goldcoast infection in Hungary in 2009. Euro Surveill. 2013;18(11):20422. Available from: PMID:23517870

69. Nhu Nguyen TM, Ilef D, Jarraud S, Rouil L, Campese C, Che $\mathrm{D}$, et al. A community-wide outbreak of legionnaires disease linked to industrial cooling towers--how far can contaminated aerosols spread? J Infect Dis. 2006;193(1):102-11. Available from: http://dx.doi.org/10.1086/498575 PMID:16323138

70. Kuhn KG, Torpdahl M, Frank C, Sigsgaard K, Ethelberg S. An outbreak of Salmonella Typhimurium traced back to salami, Denmark, April to June 2010. Euro Surveill. 2011;16(19):19863. Available from: http://www.eurosurveillance.org/ViewArticle. aspx?Articleld=19863 PMID: 21596006

71. Guerin PJ, Nygard K, Siitonen A, Vold L, Kuusi M, de Jong B, et al. Emerging Salmonella Enteritidis anaerogenic phage type 14b: outbreak in Norwegian, Swedish and Finnish travellers returning from Greece. Euro Surveill. 2006;11(2):599. Available from: PMID:16525196

72. Crook PD, Aguilera JF, Threlfall EJ, O’Brien SJ, Sigmundsdóttir $\mathrm{G}$, Wilson D, et al. A European outbreak of Salmonella enterica serotype Typhimurium definitive phage type $204 \mathrm{~b}$ in 2000 . Clin Microbiol Infect. 2003;9(8):839-45. Available from: http:// dx.doi.org/10.1046/j.1469-0691.2003.00655.x PMID:14616705

73. Eriksen HM, Guerin PJ, Nygård K, Hjertqvist M, de Jong $B$, Rose AMC, et al. Gastro-enteritis outbreak among Nordic patients with psoriasis in a health centre in Gran Canaria, Spain: a cohort study. BMC Infect Dis. 2004;4:45. Available from: http://dx.doi.org/10.1186/1471-2334-4-45 PMID:15511300

74. Spala G, Panagiotopoulos T, Mavroidi N, Dedoukou X, Baka A, Tsonou P, et al. A pseudo-outbreak of human $\mathrm{A} / \mathrm{H}_{5} \mathrm{~N}_{1}$ infections in Greece and its public health implications. Euro Surveill. 2006;11(11):658. Available from: PMID:17206026

75. Sartz L, De Jong B, Hjertqvist M, Plym-Forshell L, Alsterlund $\mathrm{R}$, Löfdahl S, et al. An outbreak of Escherichia coli $\mathrm{O}_{157}: \mathrm{H}_{7}$ infection in southern Sweden associated with consumption of fermented sausage; aspects of sausage production that increase the risk of contamination. Epidemiol Infect. 2008;136(3):370-80. Available from: http://dx.doi.org/10.1017/ So950268807008473 PMID:17445322

76. Pontrelli G, Boccia DDI, Renzi M, Massari M, Giugliano $\mathrm{F}$, Celentano LP, et al. Epidemiological and virological characterization of a large community-wide outbreak of hepatitis $A$ in southern Italy. Epidemiol Infect. 2008;136(8):1027-34. Available from: http://dx.doi. org/10.1017/So95026880700951X PMID:17892633

77. Guzman-Herrador B, Vold L, Comelli H, MacDonald E, Heier BT, Wester AL, et al. Outbreak of Shigella sonnei infection in Norway linked to consumption of fresh basil, October 2011. Euro Surveill. 2011;16(44):20007. Available from: PMID:22085618

78. Doyle A, Barataud D, Gallay A, Thiolet JM, Le Guyaguer S, Kohli E, et al. Norovirus foodborne outbreaks associated with the consumption of oysters from the Etang de Thau, France, December 2002. Euro Surveill. 2004;9(3):451. Available from: PMID:15075483

79. Mailles A, Capek I, Ajana F, Schepens C, Ilef D, Vaillant V. Commercial watercress as an emerging source of fascioliasis in Northern France in 2002: results from an outbreak investigation. Epidemiol Infect. 2006;134(5):942-5. Available from: http://dx.doi.org/10.1017/S095026880600611X PMID:16569267

8o. Rota MC, Pontrelli G, Scaturro M, Bella A, Bellomo AR, Trinito $\mathrm{MO}$, et al. Legionnaires' disease outbreak in Rome, Italy. Epidemiol Infect. 2005;133(5):853-9. Available from: http:// dx.doi.org/10.1017/S0950268805004115 PMID:16181505
81. Siret V, Barataud D, Prat M, Vaillant V, Ansart S, Le Coustumier A, et al. An outbreak of airborne tularaemia in France, August 2004. Euro Surveill. 2006;11(2):598. Available from: PMID:16525197

82. Spada E, Genovese D, Tosti ME, Mariano A, Cuccuini M, Proietti $L$, et al. An outbreak of hepatitis A virus infection with a high case-fatality rate among injecting drug users. J Hepatol. 2005;43(6):958-64. Available from: http://dx.doi.org/10.1016/j. jhep.2005.06.012 PMID:16143420

83. Ansaldi F, Marensi L, Puppo S, Rosselli R, Turello V, Zoppi G, et al. Molecular epidemiology and case-control approaches for management of an outbreak of hepatitis A in Liguria, Italy. J Prev Med Hyg. 2007;48(3):103-8. PMID:18274347

84. Dominguez M, Jourdan-Da Silva N, Vaillant V, Pihier N, Kermin C, Weill FX, et al. Outbreak of Salmonella enterica serotype Montevideo infections in France linked to consumption of cheese made from raw milk. Foodborne Pathog Dis. 2009;6(1):121-8. Available from: http://dx.doi.org/10.1089/ fpd.2008.0086 PMID:19072083

85. Rimšelienė G, Vold L, Robertson L, Nelke C, Søli K, Johansen $\mathrm{OH}$, et al. An outbreak of gastroenteritis among schoolchildren staying in a wildlife reserve: thorough investigation reveals Norway's largest cryptosporidiosis outbreak. Scand J Public Health. 2011;39(3):287-95. Available from: http://dx.doi. org/10.1177/1403494810396557 PMID:21321048

86. Kuo HW, Schmid D, Schwarz K, Pichler AM, Klein H, König $C$, et al. A non-foodborne norovirus outbreak among school children during a skiing holiday, Austria, 2007. Wien Klin Wochenschr. 2009;121(3-4):120-4. Available from: http:// dx.doi.org/10.1007/s00508-008-1131-1 PMID:19280137

87. Robesyn E, De Schrijver K, Wollants E, Top G, Verbeeck J, Van Ranst M. An outbreak of hepatitis A associated with the consumption of raw beef. J Clin Virol. 2009;44(3):207-10. Available from: http://dx.doi.org/10.1016/j.jcv.2008.12.012 PMID:19179106

88. Rimhanen-Finne R, Niskanen T, Lienemann T, Johansson T, Sjöman M, Korhonen T, et al. A nationwide outbreak of Salmonella bovismorbificans associated with sprouted alfalfa seeds in Finland, 2009. Zoonoses Public Health. 2011;58(8):589-96. Available from: http://dx.doi.org/10.1111/ j.1863-2378.2011.01408.x PMID:21824360

89. Jansen A, Frank C, Prager R, Oppermann H, Stark K. (Nationwide outbreak of Salmonella Give in Germany, 2004). Z Gastroenterol. 2005;43(8):707-13.German. http://dx.doi. org/10.1055/s-2005-858256 PMID:16088767

90. Chan EH, Brewer TF, Madoff LC, Pollack MP, Sonricker AL, Keller M, et al. Global capacity for emerging infectious disease detection. Proc Natl Acad Sci USA. 2010;107(50):21701-6. Available from: http://dx.doi.org/10.1073/pnas.1006219107 PMID:21115835

91. Ward M, Brandsema P, van Straten E, Bosman A. Electronic reporting improves timeliness and completeness of infectious disease notification, The Netherlands, 2003. Euro Surveill. 2005;10(1):513. Available from: PMID:15701937

92. Samoff E, Fangman MT, Fleischauer AT, Waller AE, Macdonald PD. Improvements in timeliness resulting from implementation of electronic laboratory reporting and an electronic disease surveillance system. Public Health Rep. 2013;128(5):393-8. Available from: PMID:23997286

93. Hulth A, Andrews N, Ethelberg S, Dreesman J, Faensen D, van Pelt W, et al. Practical usage of computer-supported outbreak detection in five European countries. Euro Surveill. 2010;15(36) 15(36).pii:19658. PMID:20843470

94. O’Brien SJ, Gillespie IA, Sivanesan MA, Elson R, Hughes C, Adak GK. Publication bias in foodborne outbreaks of infectious intestinal disease and its implications for evidence-based food policy. England and Wales 1992-2003. Epidemiol Infect. 2006;134(4):667-74. Available from: http://dx.doi.org/10.1017/ So950268805005765 PMID:16420723 